Research Article

\title{
Utilization of Plants in the Traditional Ceremony Panggih Pengantin in Jombang Regency as Herbarium
}

\author{
Anti Qurrota A'yuni ${ }^{1^{\star}}$, Mucharommah Sartika Ami ${ }^{1}$ \\ ${ }^{1}$ Department of Biology Eduacation, Faculty of Education, University of K.H Wahab Hasbulloh, Jombang, \\ Indonesia
}

*email:_antiqurrota097@gmail.com

\section{Keywords: \\ Herbarium \\ Learning Media \\ Panggih Pengantin \\ Traditional Ceremony \\ Jombang Regency}

Submitted: $20 / 05 / 2021$

Revised: $25 / 05 / 2021$

Accepted: 07/06/2021

\begin{abstract}
The development of learning media based on local wisdom was needed to provide knowledge to the younger generation about their local culture. Local wisdom contains various positive values including pedagogical values so that they can be integrated into learning media. One of local wisdom that was still maintained by the people in Jombang Regency was the traditional ceremony Panggih Pengantin. In this series of traditional ceremony, various types of plants were used which can be used as Kingdom Plantae learning material in biology subjects. The learning media developed in this study was a herbarium. The purpose of this study was to describe the feasibility of the herbarium based on expert validation. This research was a type of research and development (R\&D) that used five stages, namely potentials and problems, data collection, product design, design validation, and design revision. The instruments used were interview guides, observation sheets, questionnaires for herbarium expert and learning media expert. The data obtained were analyzed descriptively. The herbarium developed received a score of 80 (quite feasible) from the herbarium expert and a score of 95 (very feasible) from the learning media expert. The herbarium required a little revision according to the validators' suggestions, so it was suitable for use as a biology learning media.
\end{abstract} and reproduction in any medium, provided the original work is properly cited. (02021 by author.

\section{INTRODUCTION}

Local wisdom is an idea that arises and develops continuously in a society in the form of customs, values, rules, norms, cultures, languages, believes, and daily habits (Pingge, 2017). The local wisdom of the Indonesian people is the nation's cultural wealth that needs to be preserved. There are various types of local wisdom, one of which is a traditional ceremony that is carried out to mark an important event in people's lives. Traditional ceremonies in each region have their own characteristics that show their regional identity. In Jombang Regency, there are many traditional ceremonies that are still maintained by the community. One of these traditional ceremonies in the bridal ceremony called Panggih Pengantin. This traditional 
ceremony means the bride and groom meet to start a new life together.

The results of interviews with three informants, who understand and are experts about Panggih Pengantin, revealed that there are various types of plants used in this traditional ceremony. It is known that there are about 52 plant species that are commonly used in a series of Panggin Pengantin. Some of the main species that must be available are rose flowers, jasmine flowers, ylang flowers, magnolia flowers, pandan leaves, betel leaves, gambier fruit, areca nut, and banana. The diversity of plants in the traditional bridal ceremony is very potential to be used as a material for developing learning media. Form of learning media that can be developed is a herbarium. Herbarium is a plant that is dried and displays its morphological characteristics (Muflihaini, 2017).

The development of a herbarium using plant samples from the traditional ceremony "Panggih Pengantin" has never been carried out. This development is expected to produce alternative learning media to study plant structures and provide education to students about local wisdom in their area. Learning that inserts local wisdom in it is very important for students, because it can foster a love of national culture and a desire to preserve it (Zannah, 2014). The purpose of this study was to describe the feasibility of the herbarium which was developed based on the validation results of the herbarium expert and learning media expert. The herbarium can be used to teach Kingdom Plantae material in biology subjects.

\section{METHODS}

\subsection{Research Design}

The type of research is research and development (R\&D), which refers to the
Borg \& Gall (1989) development model with a procedure that has been modified by Sugiyono used five stages, namely potentials and problems, data collection, product design, design validation, and design revision. (Sugiyono, 2019).

This research was conducted on February 12, 2021, in the Jombang Regency area, especially in the Jombang, Peterongan, and Gudo Districts. In the first stage, an analysis of the potentials and problems that underlie the development of the herbarium is carried out. Identified potentials are the many types of plants used in traditional ceremony Panggih Pengantin, so that they can be a learning source for Kingdom Plantae material.

The problem found was the unavailability of herbarium based on local wisdom as learning media. The second stage is the data collection on the types of plants in traditional ceremony that can be made into herbarium. The types of plants used in the making of the herbarium collection in this study were the types of plants used in the Balangan, Wijik Dadi, Kacar Kucur in the series of traditional ceremonies of Panggih Pengantin in Jombang Regency. The next stage is the preparation of the herbarium design and validation instruments. The herbarium that have been developed are further validated by herbarium expert and learning media expert. Products that have been validated, then revised according to suggestions from the validators.

\subsection{Instruments}

The research instruments used were interview guide (the questions asked in the interview guide only cover the series of processions for the Panggih Pengantin traditional ceremony in Jombang Regency and the types of plants used in the Panggih 
Pengantin traditional ceremony in Jombang Regency), observation sheets (the morphological structure of plants observed in this research observation sheet includes flowers, fruits, seeds, leaves, stems, and tubers), and questionnaires for herbarium expert and learning media expert. The interview guide was used to collect data about the types of plants used in the traditional ceremony Panggih Pengantin in Jombang Regency. The observation sheets were used to identify plant morphological features that can be displayed in the herbarium. Validation questionnaires were used to collect validator assessments of the developed herbarium.

\subsection{Data Analysis}

The data that have been collected then be analyzed descriptively. The score given by the validator for each aspect of the assessment has a range of $1-5$, with a score of 1 being the lowest score and a score of 5 being the highest score. Data in the form of a validation results score will be used to determine the feasibility of the herbarium, and calculated using the following formula. Table 1 shows the interpretation criteria about the obtained values.

$$
\text { value }=\frac{\text { total score obtained from validator }}{\text { maximum total score count }} \times 100
$$

Table 1. Feasibility Interpretation Criteria

\begin{tabular}{lll}
\hline No. & Range of Values & Criteria \\
\hline 1 & $85.01-100.00$ & very feasible \\
2 & $70.01-85.00$ & quite feasible \\
3 & $50.01-70.00$ & less feasible \\
4 & $1.00-50.00$ & not feasible \\
\hline
\end{tabular}

(Riduwan, 2018)

\section{RESULT AND DISCUSSION}

\subsection{Results}

The results of the validation by the herbarium expert are shown in Table 2, while the results of the validation by the learning media expert are shown in Table 3. Figure 1 shows an example of herbarium that has been developed.
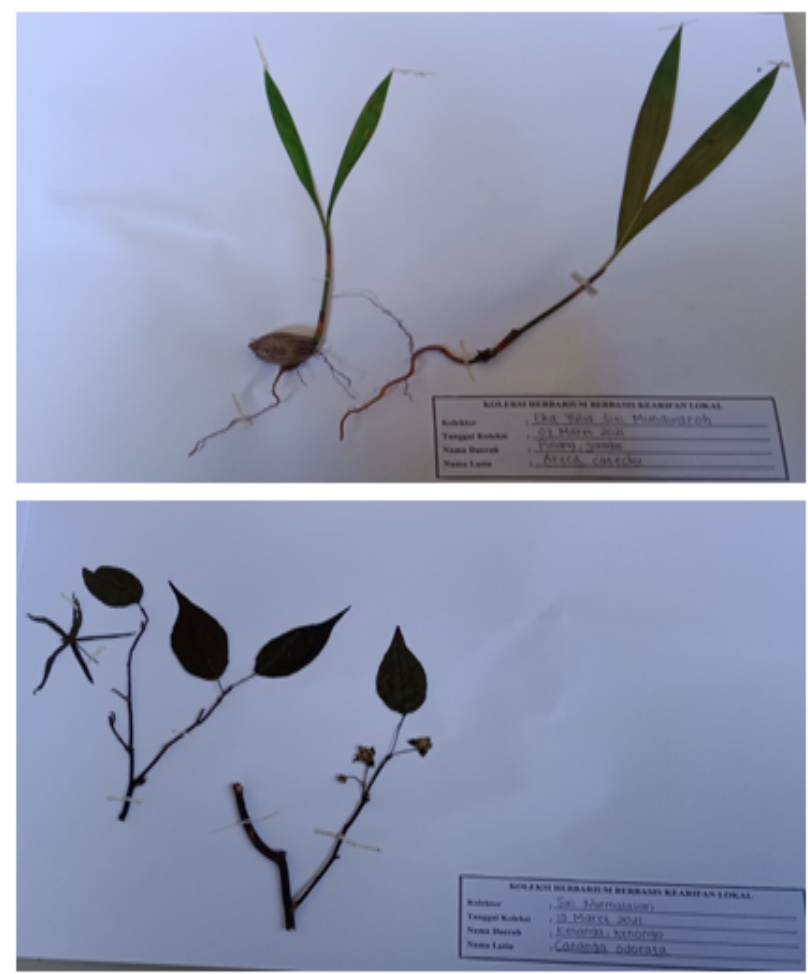

Figure 1. Example of Developed Herbarium 
Table 2. Herbarium Expert Validation

\begin{tabular}{|c|c|c|}
\hline No. & Aspects & Score \\
\hline 1 & $\begin{array}{l}\text { Plant specimens are clean, no dirt or } \\
\text { dust }\end{array}$ & 5 \\
\hline 2 & $\begin{array}{l}\text { Plant specimens are in good condition, } \\
\text { no defective organs }\end{array}$ & 4 \\
\hline 3 & $\begin{array}{l}\text { Plant specimens display vegetative } \\
\text { organs (roots, stems, leaves) }\end{array}$ & 3 \\
\hline 4 & $\begin{array}{l}\text { Plant specimens display reproductive } \\
\text { organs (flowers, fruits, seeds) }\end{array}$ & 3 \\
\hline 5 & $\begin{array}{l}\text { Herbarium label contains information } \\
\text { about the plant specimen identity }\end{array}$ & 3 \\
\hline 6 & $\begin{array}{l}\text { The scientific name of the plant } \\
\text { specimen is written according to the } \\
\text { applicable rules }\end{array}$ & 5 \\
\hline 7 & $\begin{array}{l}\text { The size of the plant specimen used is } \\
\text { proportional to the size of the paper for } \\
\text { sticking }\end{array}$ & 4 \\
\hline 8 & Neat specimen placement & 4 \\
\hline 9 & $\begin{array}{l}\text { Specimens show good morphological } \\
\text { characteristics }\end{array}$ & 4 \\
\hline 10 & Herbarium labels are easy to read & 5 \\
\hline 11 & Attractive display & 4 \\
\hline 12 & $\begin{array}{l}\text { Herbarium may be used as a learning } \\
\text { media for plant structure material }\end{array}$ & 4 \\
\hline \multirow[t]{4}{*}{13} & Good storage capacity & 4 \\
\hline & Total & 52 \\
\hline & Value & 80 \\
\hline & Criteria & Quite Feasible \\
\hline
\end{tabular}

Table 3. Learning Media Expert Validation

\begin{tabular}{clc}
\hline No. & \multicolumn{1}{c}{ Aspects } & Score \\
\hline 1 & $\begin{array}{l}\text { The suitability of the media with the } \\
\text { learning objectives, namely describing } \\
\text { the morphological structure of the plant }\end{array}$ & 5 \\
2 & $\begin{array}{l}\text { Media can be used by class X students } \\
3\end{array}$ & $\begin{array}{l}\text { Media can be used as a learning source } \\
\text { for seed plant material }\end{array}$ \\
4 & $\begin{array}{l}\text { Media can develop student motivation } \\
5\end{array}$ & 4 \\
6 & $\begin{array}{l}\text { Media can attract students' attention } \\
\text { Media can be used as a tool to }\end{array}$ & 5 \\
7 & $\begin{array}{l}\text { material } \\
\text { Media can be used as a tool to } \\
\text { remember plant morphological structure } \\
\text { material }\end{array}$ & 5 \\
& Media can be used as a tool for material & 5 \\
\hline
\end{tabular}




\begin{tabular}{|c|c|c|}
\hline & retention of plant morphological structure & \\
\hline 9 & $\begin{array}{l}\text { Media can be used as a feedback effort } \\
\text { in learning activities }\end{array}$ & 5 \\
\hline 10 & $\begin{array}{l}\text { Media according to the student learning } \\
\text { environment in the classroom }\end{array}$ & 4 \\
\hline 11 & Media easy to use & 5 \\
\hline 12 & $\begin{array}{l}\text { Media can increase the efficiency of } \\
\text { learning time }\end{array}$ & 5 \\
\hline 13 & Media is quite easy to make & 5 \\
\hline 14 & Good media display & 4 \\
\hline 15 & Media is safe for students to use & 5 \\
\hline \multirow[t]{4}{*}{16} & Media is easy to store & 5 \\
\hline & Nilai & 76 \\
\hline & Value & 95 \\
\hline & Criteria & Very Feasible \\
\hline
\end{tabular}

\subsection{Discussion}

The results validation by herbarium expert show that the criteria is quite feasible with a value of 80 . The highest score in the validation questionnaire is 5 , there are three aspects that get it. Aspect number 1 regarding specimen cleanliness got a score of 5 because there was no impurities in the herbarium specimen. The herbarium that has been developed meets the criteria of a good herbarium, which is to have a clean and tidy appearance (Afifah et al., 2017). Aspect number 6 regarding the writing of scientific names gets a score of 5 because it meets the rules for writing the binomial nomenclature. Binomial Nomenclature introduced by Carolus Linnaeus. The first part of the binomial is the name of the genus, the second part is the name of the species. The first letter of the genus is written in capital letters while the first species letter is written in lower case all binomials are italicized (Reece et al., 2014). Aspect number 10 concerning herbarium label legibility also scored 5 because the type and size of the letters used were proportional and the placement on the specimen paper was correct. Label functions as identification card or personal identity of the specimen in the herbarium (Muflihaini, 2017).

The lowest score that given by the herbarium expert in the questionnaire is 3 , and there are three aspects that get it. Aspect number 3 and 4 concerning the appearance of vegetative and reproductive organs in the herbarium got a score of 3 because there were some specimens that did not display the organs completely. This happens because some plant specimens are relatively large so that they do not fit in one piece of paper as a whole. The sample size of the herbarium is usually $30 \times 40 \mathrm{~cm}$, taking into account the completeness of the organs in the form of fertile roots, stems, and leaves. If the sample size is more than $30 \times 40 \mathrm{~cm}$, the thing to pay attention to is that the organs in the plant must not be cut or separated, but just fold according to the mounting paper (Murni et al., 2015). Aspect number 5 regarding the content of the information in the herbarium label gets a score of 3 because it has not include the name of the plant in Indonesian. The validator suggests adding plant names in Indonesian to make it more informative for users. The other seven aspects got a score of 4 which indicates that the herbarium has 
met the requirements according to the determined assessment criteria.

The results of the validation by learning media expert show that the criteria is very feasible with a value of 95 . As many as 12 aspects of the assessment from all 16 aspects got a score of 5 . This shows that these aspects have been fulfilled in the herbarium developed, while four other aspects got a score of 4 . Aspect number 2 regarding the ability of the media to be used by class $X$ students gets a score of 4 . This is because in class $X$ there is material on Kingdom Plantae, but the types of plants made by the herbarium are still incomplete. Herbarium can help students learn the plant classification (Maula \& Ulfa, 2016) and plant structure. Aspect number 3 regarding the ability of the media as a learning source for seed plant material gets a score of 4 because it has not shown any examples of Gymnosperms. Gymnosperms cannot be displayed because this herbarium was developed based on the traditional ceremony Panggih Pengantin that did not use this type of plant.

Aspect number 10 regarding the suitability of the media with the learning environment of students in the class gets a score of 4 because the herbarium developed can be used in classroom learning. The use of herbarium in classroom learning makes students more active in learning (Syamsiah et al., 2020). The existence of herbarium make learning more efficient because the teacher does not need to look for fresh plants as a learning source, which can take up time, and can also improve student learning outcomes (Asra et al., 2019). Aspect number 14 regarding the appearance of the media gets a score of 4 because the condition of the specimens is quite good but there are some specimens that display colors that are very different from the original color. This discoloration is caused by the drying process, but does not really affect the morphological structure of the specimen so that it can still provide information to the users. Herbarium is an example of visual learning media which is known to be more effective in increasing student motivation (Tafonao, 2018). The use of herbarium in learning provides meaningful learning experiences for students (Rezeqi \& Handayani, 2018). The development of a herbarium based on local wisdom can be an alternative learning medium to study plant structures and provide education to students about local wisdom in their area. The integration of local wisdom in learning in schools is very important as an effort to create learning that not only equips students with knowledge but also instills a sense of love for local diversity in their environment (Pingge, 2017).

\section{CONCLUSION}

The herbarium expert's assessment showed that the herbarium that met the criteria was quite feasible with a value of 80 . As for the assessment of the learning media expert, it showed that the herbarium was very feasible with a value of 95 . Both validators suggested to do a little revision of the herbarium before using it as a learning media. The herbarium specimens used were dominated by angiosperms, while the gymnosperms were still few. The collection of herbarium specimens for dicotyledonous and monocotyledonous species is still incomplete, so it would be better if the herbarium collection consisted of dicotyledons and monocots in full. In general, the herbarium developed is suitable as a learning media. Other researchers who have the same interest can develop herbarium with other types of 
plants, such as Gymnosperms that have not been included in this study.

\section{References}

Afifah, N., Sudarmin \& Widianti, T. (2014). Efektivitas Penggunaan Herbarium dan Insektarium pada Tema Klasifikasi Makhluk Hidup sebagai Suplemen Media Pembelajaran IPA Terpadu Kelas VII MTs. Unnes Science Education Journal, 3(2), 494-501.

Afifah, N., Windayat, V. P. \& Karno, R. (2017). Kelayakan Media Pembelajaran Biologi dalam Bentuk Spesimen pada Materi Organ Tumbuhan di SMPN 5 Rambah Hilir. J. Sainstific MIPA, 1(1), 7-13.

Asra, Revis, Johari, A. \& Haryadi, B. (2019). Pemanfaatan Media Herbarium untuk Meningkatkan Hasil Belajar Siswa di Pondok Pesantren Al Hidayah. Jurnal Karya Abdi Masyarakat, 3(1), 41-46.

Dahlia. (2020). Pengembangan Herbarium Book sebagai Media Pembelajaran Biologi pada Mata Kuliah Morfologi Tumbuhan Mahasiswa Jurusan Pendidikan Biologi Universitas Pasir Pengairan. Jurnal BioEdu, 4(1), 13-16.

Marlina, S., Panjaitan, R. G. P. \& Aryati, E. (2016). Pengembangan Herbarium Hasil Inventarisasi Tumbuhan Obat sebagai Media Pembelajaran pada Subpokok Bahasan Angiospermae. Jurnal Pendidikan dan Pembelajaran Khatulistiwa, 5(2), 1 12.

Maula, M. A. S. \& Ulfa, M. (2016). Wayang Herbarium pada Pembelajaran
Klasifikasi Tumbuhan. Prosiding Seminar Nasional Sains dan Enterpreneurship III, 104-109.

Muflihaini, M. A. (2017). Herbarium Kering. Magelang: UNTIDAR.

Mulyono, D. (2002). Mutiara di Balik Tata Cara Pengantin Jawa. Jakarta: Pusat Bahasa.

Murni, P., Muswita, Harlis, Yulianti, U. \& Kartika, W. D. (2015). Lokakarya Pembuatan Herbarium untuk Pengembangan Media Pembelajaran Biologi di MAN Cendikia Muaro Jambi. Jurnal Pengabdian Masyarakat, 30(2), 16.

Pingge, H. D. (2017). Kearifan Lokal dan Penerapannya di Sekolah. Jurnal Edukasi Sumba, 1(2), 128-135.

Reece, J. B., Urry, L. A., Cain, M. L., Wasserman, S. A., Minorsky, P. V. \& Jackson, R. B. (2014). Campbell Biology, 10th Edition. USA: Pearson Education, Inc

Rezeqi, S. \& Handayani, D. (2018). Pengembangan Media Pembelajaran Pterydophyta Berbasis Herbarium. Jurnal Pelita Pendidikan, 6(1), 36-41.

Riduwan. (2018). Skala Pengukuran Variabel-Variabel Penelitian. Bandung: Alfabeta.

Sugiyono. (2019). Metode Penelitian Kuantitatif, Kualitatif, dan R\&D, Edisi 2. Bandung: Alfabeta.

Syamsiah, B., Nurhayati \& Hiola, S. F. (2020). Pemanfaatan Spesimen Herbarium sebagai Media Pembelajaran bagi Guru-Guru IPA/Biologi di Kabupaten 
Enrekong. Jurnal Dedikasi, 22(1), 99-103.

Tafonao, T. (2018). Peranan Media Pembelajaran dalam Meningkatkan Minat Belajar Mahasiswa. Jurnal Komunikasi Pendidikan, 2(2), 103114.

Zannah, U. (2014). Makna Prosesi Perkawinan Jawa Timur sebagai Kearifan Lokal (Pendekatan Etnografi Komunikasi dalam Upacara Tebus Kembar Mayang di Desa Jatibaru, Kecamatan Bungaraya, Kabupaten Siak, Provinsi Riau). Jom FISIP, 1(2), 115. 